\title{
Inaccessible Fields: Doing Anthropology in the Malian Political Turmoil
}

\section{Sten Hagberg and Gabriella Körling}

\section{(Q) OpenEdition}

\section{Journals}

Electronic version

URL: http://journals.openedition.org/anthropodev/308

DOI: 10.4000/anthropodev.308

ISSN: 2553-1719

\section{Publisher}

APAD - Association pour l'anthropologie du changement social et du développement

\section{Printed version}

Date of publication: 1 September 2014

Number of pages: 143-159

ISBN: 9791093476018

ISSN: 2276-2019

\section{Electronic reference}

Sten Hagberg and Gabriella Körling, « Inaccessible Fields: Doing Anthropology in the Malian Political Turmoil », Anthropologie \& développement [Online], 40-41 | 2014, Online since 01 September 2016, connection on 19 April 2019. URL : http://journals.openedition.org/anthropodev/308 ; DOI : 10.4000/ anthropodev.308

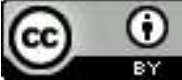

La revue Anthropologie \& développement est mise à disposition selon les termes de la Licence Creative Commons Attribution 4.0 International. 


\title{
Inaccessible Fields: Doing Anthropology in the Malian Political Turmoil
}

\author{
Sten Hagberg and Gabriella Körling
}

Cet article s'appuie sur une recherche comparative en cours sur les oppositions socio-politiques dans les communes du Burkina Faso, du Mali et du Niger. Ici, nous nous intéressons plus particulièrement à ce qui arrive au chercheur quand le terrain devient inaccessible pour pratiquer l'ethnographie. Au Mali, notre recherche sur les politiques municipales dans deux communes avait commencé en octobre 2011 et aurait dû se poursuivre les années suivantes. Mais, avec le coup d'Etat du 22 mars 2012 qui plongea le Mali dans la violence en produisant une partition de facto du pays, notre enquête de terrain dans les deux municipalités dut être suspendue. Et pourtant, les développements politiques de la crise malienne ouvrirent un nouvel espace de discussion et de débat. En effet, en tant que chercheurs, nous fûmes vite interpellés pour analyser et commenter la crise malienne, tant dans les medias que dans les revues scientifiques. En tant qu'anthropologues, nous étions mal à l'aise pour proposer une analyse d'un terrain aussi inaccessible, ce qui n'était pas du tout le cas de nombreux autres chercheurs, tels les politistes et les économistes. Nous pensons que notre rapport aux terrains inaccessibles révèle quelque chose d'important sur la compréhension anthropologique du terrain et des relations d'enquête.

C'est ainsi que notre papier interroge la manière dont, malgré tout, nous avons fait de l'anthropologie sur des terrains devenus inaccessibles à cause du bouleversement politique malien. Nous développons des exemples sur la manière dont nous avons analysé les débats médiatiques, dirigé des études de cas à distance et dialogué avec les Maliens impliqués dans les réseaux sociaux afin de poursuivre la recherche tout en étant empêchés d'aller sur les terrains en question. Aussi surprenant que cela puisse paraître, nous pensons que ces terrains inaccessibles nous ont obligés, concrètement et pratiquement, à trouver d'autres sortes d'éclairages empiriques. Dans le texte, nous discutons tout particulièrement la manière dont l'analyse anthropologique des termes du débat public malien éclaire 
de manière pertinente les représentations et les stéréotypes qui traversent les discours politiques locaux dans le pays.

This paper is based on ongoing comparative research on sociopolitical opposition in municipalities of Burkina Faso, Mali and Niger. Here we are particularly focusing on what happens to anthropological researchers when field settings become inaccessible for first-hand ethnographic observation. In Mali fieldwork on municipal politics began in two field sites in October 2011 with the intention to pursue research there over the coming years. Yet with the coup d'état on 22 March 2012 that plunged Mali into violence, and a de facto partition of the country our fieldwork in the two municipalities had to be postponed. And, yet, political developments of Malian crisis opened up a completely new field of discussion and debate. As researchers we were soon asked to comment and reflect on the country's prospects both in media and in academic journals. As anthropologists we felt troubled to conduct an analysis of such inaccessible fields, whereas many scholars of other disciplines, such as political scientists and economists, apparently did not. It is our contention that our handling of inaccessible fields does say something significant about anthropological understandings of field and fieldwork relations.

The paper discusses how - as a consequence of the Malian political turmoil - we have been doing anthropology in inaccessible fields. We elaborate examples of how we have been analysing media debates, monitoring case-studies at distance, and dialoguing with Malian stakeholders in social media as to pursue research despite being unable to enter the specific field settings. Interestingly, we do think that such inaccessible fields have, concretely and practically, obliged us to get other kinds of empirical insights. In the paper, we particularly discuss the extent to which the systematic and grounded anthropological study of Malian public debate offers valuable insights into representations and stereotypes that resonate with local discourses in the country.

\section{Introduction}

In this paper we discuss the dilemmas anthropologists face when field settings become inaccessible for first-hand ethnographic observation. The paper is based on on-going comparative research on socio-political opposi- 
tion in rural and urban municipalities in Burkina Faso, Mali and Niger. In Mali, fieldwork on municipal politics began in two field sites in October 2011 with the intention to pursue research there over the coming years. Yet with the coup d'état on 22 March 2012 that plunged Mali into a turmoil of war and violence, and led to the de facto partition of the country, our fieldwork in the two municipalities had to be postponed. As researchers we were soon asked to comment and reflect on the country's prospects both in media and in academic journals. As anthropologists we initially felt troubled to conduct an analysis from afar, especially given the fact that we had rather limited fieldwork to draw on. However, we soon realised that the requests for commentary on the Malian crisis actually opened up a completely new field of focus and form of analysis. The inaccessibility of the field obliged us to engage with other kinds of empirical material which, despite their obvious limitations, has led to new insights. Hence, we contend that coping with inaccessible fields evokes questions about conventional anthropological understandings of "the field" and of "fieldwork relations", such as the danger of automatically equating fieldwork with representative authority and of reducing the discipline of anthropology to the method of participant observation ${ }^{1}$.

A number of anthropologists have discussed different dimensions of violence and fieldwork. One important work is the collection of essays Anthropology Under Fire: Contemporary studies of violence and culture (Nordstrom \& Robben, 1997) that focuses on epistemological dimensions such as the lived experience of violence of the people studied, as well as, of the fieldworker. Others have focused on the implications for fieldwork strategies when working in a dangerous field such as the necessity of negotiating and adapting methods and ethics (Kovats-Bernat, 2002). Others put the ethnographic analysis of people's living in and beyond conflict to the fore (Richards, 2005). Two APAD Bulletins have also been discussing en-

${ }^{1}$ This paper is the result of a continuous dialogue within the research team. The Malian research assistants - all students in anthropology at Institut Supérieur de Formation et de Recherche Appliquée (ISFRA), University of Bamako - are Bintou Koné, N'gna Traoré and Bassidy Dembele, to whom we hereby express our acknowledgements. We also thank more generally our interlocutors in the municipalities of Kiban and Kalabancoro. A special mention to the research institute Point Sud for providing the institutional basis for our research in Mali. 
demic violence (No 25, 2003) and social violences and exclusions (No 27$28,2008)$. Common to these studies is the focus on the ethnography of violence and conflict, and how to deal with dangerous situations with sometimes inaccessible fields. In this paper, however, our intention is to discuss alternative research strategies when having chosen not to go to back to the field because of security concerns due to the outbreak of sociopolitical unrest and conflict. In other words, the paper takes seriously the option of how to pursue anthropological research despite an inaccessible field in order to explore how "the field" can be redefined to open up for new conceptual and methodological terrains. While we do not have any ambition to add to the postmodern critique against the ways in which anthropologists construct "the field" we do argue that situations of an inaccessible field may incite us to innovatively think about new ways of constructing the ethnographic material.

We develop our argument in three parts. In the first part we account for how we dealt with the dilemma posed by the demands for analysis of the rapidly unfolding situation in Mali coupled with the absence of firsthand ethnographic fieldwork of the conflict by instead choosing to analyse Malian media and public debate following the coup d'état. In the end, the systematic and grounded anthropological study of Malian public debate offered interesting insights into the circulation of representations and stereotypes in local discourses in Mali and also led us to reflect more on national political dynamics in Mali today and in the past. In the second part of the paper we elaborate on our research strategies both in terms of practical aspects of fieldwork and in terms of a partial re-conceptualisation of the framing of the study given the extended political crisis. In the third part of the paper we problematize the equation between fieldwork and representative authority in light of our experiences of trying to do anthropology in the political turmoil of present-day Mali. 


\section{Analysing public discourses in the midst of political turmoil}

The research project in question is a three-year comparative project on municipal politics in Niger, Burkina Faso and Mali². By the comparative study of political practice in a selected number of municipalities, we seek to understand expressions and articulations of socio-political opposition. We approach "socio-political opposition" broadly as to encompass formal political processes, social movements, development interventions and everyday resistances and protests. Such a broad approach to socio-political opposition is motivated by the fact that despite two decades of democratisation formal political opposition remains weak in West Africa. It is therefore necessary, we argue, to broaden the concept of opposition to include formal and informal, as well as organized and spontaneous, collective action. Methodologically, fieldwork is conducted in selected urban and rural municipalities in the three countries, focusing on formal political processes, development and infrastructure investments, as well as popular contest. Drawing on previous fieldwork in Burkina Faso (Hagberg since 1988) and Niger (Körling since 2004) we work together in Mali as to sharpen the research project's comparative insights. We focus on the municipality as an arena where heterogeneous actors intervene with local and external resources, a public space where state actors and citizen representatives interact around multiple norms with respect to access to public goods and services, and a locus for political imagination, cultural representation and symbolic meaning (Hagberg, 2009; see also Olivier de Sardan, 2005).

As stated in the introduction fieldwork in Mali - in the municipalities of Kalabancoro and Kiban - began in October 2011 with the aim of returning at regular intervals, like in Niger and Burkina Faso, to follow up on developments in each municipality ${ }^{3}$. In Mali the second fieldwork was tentative-

\footnotetext{
${ }^{2}$ The research project is entitled Spheres of Opposition? Democratic Culture and Local Development in West African Municipalities and is funded Sida's research council (see www.antro.uu.se/en/cultural-anthropology/research/projects/spheres-of-opposition/).

${ }^{3}$ The selection of these municipalities was based on the need to have one rural and one periurban municipality. The final choice of Kalabancoro and Kiban was guided by the fact that the specific problems encountered in the settings were common to many municipalities and also because previous fieldwork had been carried out there (see Hagberg et al., 2009).
} 
ly planned to take place during the elections that were supposed to have marked the end of Amadou Toumani Touré's - nicknamed ATT - presidency. The elections were surrounded by uncertainty given the outbreak of violence in the North in January 2012 and the coup d'état on 22 March 2012 temporarily put an end to any plans to do fieldwork in Mali in the near future. The coup d'état propelled the country onto the stage of international media. Mali had often been depicted as a democratic success story in Africa, and to many, the coup d'état and the rapid unravelling of stability came as a surprise. All of the sudden there was an important demand for analysis and explanation of the crisis. The days following the coup d'état we were increasingly asked to intervene in public debate and provide background context to what soon became "the Malian crisis" ${ }^{4}$. As many other colleagues working in the country, the demands for information and analysis meant that we were urged to respond when for once the Sahel became a locus of attention to journalists and news agencies ${ }^{5}$.

Not being able to go to the field we closely followed the events from afar via internet, social media and the analysis of seasoned Mali experts. We were also asked by one of the editors of an academic journal to reflect on the crisis in an article. In the absence of field material on the current crisis we chose to analyse public debate through the study of Malian media by consulting print media easily accessible on the internet, as well as, various public declarations following the coup d'état. We focused on how the Malian political class, the international community, and the de facto partition of the country following the takeover of the North by Tuareg and Islamist movements were discussed in public debate in order to elicit prevailing representations and stereotypes in the months following the coup d'état. We felt that the focus on national debates was important, especially as these were rarely taken into account in international media reports and analysis. At the same time it was necessary to contextualise not only

\footnotetext{
${ }^{4}$ Hagberg was interviewed on Swedish Radio at several occasions (Sveriges Radio, 23 March 2012, 22 August 2012, and 29 January 2013), and was furthermore frequently asked to comment to Swedish newspapers. In June 2012 Körling participated with a paper in the conference on Post-Gaddafi repercussions in the Sahel at the Kofi Annan Peacekeeping Training Centre (KAIPTC) in Accra to discuss the increasing political unrest in the Sahel. The conference was a joint venture between the KAIPTC and the Nordic Africa Institute.

${ }^{5}$ For a critical reflection on these media images of Africa, see Hagberg 2012.
} 
the national debate but also the rapid unravelling of the Malian nationstate and the heated party politics in Bamako. We thus highlighted the contradictions of the democratization process in Mali especially when it comes to party political dynamics. In particular we analysed President Touré's politics of consensus as well as the complex relations between the Tuaregs and the Malian state (Hagberg \& Körling, 2012).

The reading and skimming through of newspaper articles and editorials gave us insights into the public debate in Bamako such as the division between supporters and opponents of the coup d'état. This was reflected not only in the division of the Malian political class but also in the media. There were two radically different readings of the coup d'état, and the political class was divided into two camps. One camp was political parties ${ }^{6}$, trade unions and associations that opposed the coup and soon came together in the United Front for the Protection of Democracy and of the Republic (FDR). Another camp was composed of organizations and political parties, most notably the leftist party of Oumar Mariko, Solidarite Africaine pour le Développement et l'Indépendance (SADI), that formed the Popular Movement of 22 March 2012 (MP-22) to support the coup, and "politically accompanying" the junta in their efforts to "re-establish democracy" (Hagberg \& Körling, 2012 : 118). This polarization of the political class was clearly revealed in Bamako based newspapers, especially in editorials. While in reproachful editorials, the coup was seen as a serious setback for democracy, editorials supportive of the coup pointed to the mismanagement of ATT whose regime was associated with corruption and nepotism. The junta in its turn played on a longstanding "popular discontent regarding the political class" (Van de Walle, $2012: 12$ ) to legitimise the coup. At the same time as the international image of Mali as a democratic success story was quickly unravelling the public debate in Bamako was very much centred on the failures of President Touré's regime and, more generally, of the political class.

The prospect of outside intervention was also discussed at great length especially the role of ECOWAS who initially was the main actor in the me-

${ }^{6}$ It should be noted that the biggest political parties - such ADEMA, URD CNID, RPM, UDD, and PARENA - all condemned the coup. 
diation of the political crisis in Bamako following the coup d'état, a crisis that continued also during the transition period. Opponents of external intervention were the most vocal. However, support for this opposition wore of as the violence in the North continued and spread southward. Finally, the Bamako based media was united in dismissing the claims of the MNLA and the Tuareg independence movement.

In the end, writing the article gave us important insights into the circulation of representations and stereotypes in local discourses in Mali at a time when little attention was paid to these aspects. Some of these might now seem dated but they still give an idea of the mood in the months following the coup d'état. It also led us to reflect more on historical and contextual aspects of the crisis and on national political dynamics in Mali today and in the past to try to understand the current crisis. These were insights that we could bring back to the research project through partial re-framing of the research questions including the impact of the political crisis on the municipalities. This is the focus of the next section.

\section{Malian municipalities and the crisis}

From the outset of the project the methodological approach included a strong element of teamwork. Based on our previous individual long-term fieldwork in Burkina Faso and Niger respectively we decided that the comparative dimension of the project would only be feasible with a systematic joint-teamwork. Therefore, for the fieldwork in Mali we had already decided to work together in the two municipalities with two anthropology students from the University of Bamako as research assistants. This methodological approach helped us to develop a team spirit a bit in the same vein as practised in the ECRIS (Bierschenk \& Olivier de Sardan, 1997), and more specifically in previous work carried out in these municipalities (Hagberg et al., 2009). Thus, we were a team of two Swedish anthropologists and two Malian anthropology students who during the day worked on different aspects of municipal life and in the evening reassembled for summary and reflection of the day's work.

We had already from the beginning decided not to work in Northern Mali, but to stay in the Koulikoro Region, notably in the municipalities of 
Kiban (Banamba Cercle) and Kalabancoro (Kati Cercle). The ambition was to cover relevant issues pertaining to rural and urban municipal political life, such as agro-pastoral livelihoods and farmer-herder relations, ethnicity and autochthony, and the land question in both rural and peri-urban areas. This meant that we were not to be directly exposed to the security problems of the north for the carrying out of the fieldwork in the first place.

After the coup d'état on 22 March 2012 these different methodological considerations turned out to be very important. Our Malian research assistants for whom it was not dangerous to travel to and work in the municipalities pursued fieldwork in October-November 2012. They were already known there and well-acquainted with our field research. In particular, we asked them to also focus on the effects of the crisis in each municipality. After this fieldwork period they reported back to us and, in addition, transcribed all interviews. Through interviews with political actors in the municipalities they were able to demonstrate the ways in which public service provision and municipal council had continued to operate despite the coup d'état.

So, even though we ourselves could not travel to Mali, we could still get municipal life documented by our research assistants. It should be noted that this was a period when travelling in these parts of Mali was not deemed dangerous, and we did not in any way risk the safety of our assistants. But it was deemed dangerous for foreigners in general and Europeans in particular. Prior to and after the international military intervention in January 2013 the situation was nevertheless different and no-one was advised to travel in the country. Interestingly, however, when following news reporting in January-February 2013, it was often mayors who were the first to make public statements to international media when towns were liberated by the French air and land troops. In that context, our Malian research assistants' follow-up fieldwork in the two municipalities of Kalabancoro and Kiban were useful contextualization of the situation in Mali.

In March 2013, we were finally able to go to Bamako. On our return to Mali we were able to follow up on the research assistants' work. However, due to initial security concerns we only carried out fieldwork in the municipality of Kalabancoro which although it is a rural municipality is very much 
part of the urban agglomeration of Bamako. We pursued fieldwork on zoning of urban land, and also interviewed political actors with whom we had worked already in 2011. We did not carry out fieldwork in the municipality of Kiban. But as Kiban has an important population in Bamako, we were able to meet some of the central actors from Kiban. These were the mayor and the secretary general of the municipality, as well as members of the two most important home town associations, many of whose members are based in Bamako?.

Conclusions from our fieldwork in March 2013 combined with the research assistants' report were that despite the political turmoil at the national level the municipalities continued to function although with some disruptions, such as the financial flows from the central state. The municipalities had also lived through the retreat of development projects and support with the suspension of development cooperation in response to the coup d'état. However, new development actors had also entered the scene, especially in Kalabancoro as humanitarian actors/aid provided support to the displaced population from the North. There seems to have been a fairly strong support for the coup d'état at the same time as there was also criticism of the coup d'état. At the same time political parties seemed to have been more or less discredited.

This fieldwork was also an opportunity to define and plan for new fieldwork periods for our Malian research assistants as to do more indepth interviews and observations on specific issues ${ }^{8}$. Later on, we have been able to carry out further fieldwork during the presidential elections in July-August 2013, as well as ongoing research on municipal politics ${ }^{9}$. These fieldworks have all aimed to deepen the ethnographic material to be analysed comparatively in the research project.

\footnotetext{
${ }^{7}$ Since mid-2013 fieldwork has been regularly conducted in Kiban and Kalabancoro, thus the anthropological research context has become "normalised".

${ }^{8}$ Fieldwork was pursued in the municipalities of Kalabancoro and Kiban April-June 2013 and in the municipalities of Montougoula and Kiban in November-December 2013. Detailed reports were written by research assistants N'gna Traoré and Bintou Koné.

${ }^{9}$ Sten Hagberg and Bintou Koné conducted fieldwork in July-August and in October 2013, and in January and June 2014.
} 
To sum up, our attempt to focus on media reporting and public declarations in the Malian political turmoil to highlight the lines of cleavage and conflict and to assess how political actors positioned themselves was complemented with fieldwork conducted by research assistants and a year after with a fieldwork concentrated to the Malian capital. The sociopolitical turmoil in Mali - a country regarded as a success story among African democracies - deteriorated into what some observers called a nightmare. And, yet, municipal politics continued to operate, albeit in a very different and sometimes threatening national and international contexts.

The continuity and rupture of municipal political life - especially when it comes to socio-political opposition - is an analysis that we will carry out in future papers and publications. In this paper, however, we have so far focused on methodological problems when the field becomes inaccessible. In the final part of the paper we would like to return to the issue of representative authority in present-day anthropology, and how "the field" is constructed.

\section{What determines representative authority in anthropology?}

In the introduction to Anthropology Under Fire: Contemporary studies of violence and culture the question of what to do when unexpectedly confronted with violence is posed. What research strategy should one choose? Should the researcher carry out with the original research project as if nothing has changed, return home or study the new situation (Nordstrom \& Robben, $1997: 16)$ ? In this paper we have pragmatically described how we did in order to make the best out of an impossible situation for anthropological fieldwork. Yet beyond the specific circumstances around which we have coped with a difficult research context, we do think that our experience does outline an alternative approach in cases where the field has become inaccessible due to violent conflict and political turmoil.

The field can be inaccessible to the researcher as there may be institutional constraints that do not allow for fieldwork in such a context due to security and insurance concerns. The field can also be inaccessible because 
of a personal decision to not expose oneself to risks of violence or hostage taking. In any case, we argue that there is a middle-ground of dealing with inaccessible fields. Hence, while it is important to integrate outbursts of violence, conflict and political turmoil into an on-going research project as these events are part and parcel of the wider social, political and cultural context this can be done in many different ways.

Fieldwork and all that it entails - the creation of relations with the people studied, interviews and participant observation, informal conversations and hanging around, different degrees of immersion in a specific local contest - is at the heart of anthropology. Having access to the field is in many ways the sine qua non of anthropological research. This centrality of fieldwork persists even though traditional conceptualisations of the field as a bounded entity have been challenged in order to allow for a much greater flexibility and reflexive awareness when identifying/or delimiting the "field" (see for instance Gupta \& Ferguson, 1997). The very construction of "the field" is indeed an active engagement with conceptual and methodological issues in dialogue with the ethnographic material. To put it simply, "the field" does not exist "out there" but is constructed by the researcher's methodological conceptualisation (Amid, 2000; Leservoisier, 2005; see also Sluka \& Robben, 2007). Sluka \& Robben argue that:

"When researchers more frequently conduct long-term or diachronic fieldwork in the same location over many years and several field trips, and where the physical distance between 'home' and 'the field' is largely ameliorated by instantaneous means of electronic mass communication, this simple dichotomy between being in the field' and then leaving no longer holds sway." (Sluka \& Robben, 2007: 25)

In the same vein, sometimes the field is inaccessible and thus unreachable for first-hand ethnographic observation and sometimes it is not. And, yet, this often occurs when the anthropological gaze searching for cultural logics in everyday practice, and analysing political culture in the midst of national politics is more needed that ever.

With the coup d'état on 22 March 2012 we opted to conduct a media analysis as a complement to other kinds of ethnography. It was useful for our own understanding of the situation, and we also contributed to public 
debate and anthropological research on the Malian crisis. We would even like to argue that an anthropologically grounded mass media analysis may open up for new insights. In fact, such an analysis represents a somewhat different anthropological endeavour - it is not merely "the second best" option - but it does form part of a broader approach to anthropological research. In his study of the public debate following the assassination of Norbert Zongo - journalist and director of the Burkinabe weekly L'Indépendant - Hagberg (2002) suggests that an ethnographic account of national politics is required for understanding the specific political culture of a given country in order to grasp the socio-cultural logics underpinning national politics. The strength of an anthropologically grounded mass media analysis is that it can be combined with a careful and sensitive ethnographic understanding of public debate. In the present research in Mali, we had not planned for a systematic mass media analysis but it was forced upon us due the political crisis. Nevertheless, it did add important insights on the interplay of local, national and international issues in the Malian public debate.

We also sought to engage our research assistants much more in the process of producing ethnographic material. Thanks to the previous teamwork we were able to produce detailed instructions - in the form of terms of reference - for the follow-up fieldwork in the municipalities of Kalabancoro and Kiban. These fieldwork periods also gave them opportunities to formulate and conduct their own master degree projects ${ }^{10}$. This turned out to be a "long-distance fieldwork" with all the possible methodological challenges but counterweighted by continuous contact by means of email and social media. It was far from an ideal situation, but it did nevertheless produce interesting ethnographic material. And when we finally were able to go back to Mali again in March 2013, we did complement the mass media analysis and the long-distance fieldwork with conventional anthropological fieldwork. But simultaneously we pursued new plans for studying

\footnotetext{
10 Fieldwork of two Master students in Anthropology was funded by the research project. N'gna Traoré's research on forms and modes of expression socio-political opposition in the municipality of Mountougoula was successfully defended in September 2013. Bintou Koné's research on kinship and politics in the municipality of Kiban is work in progress.
} 
national politics, as well as, long-distance fieldwork through the research assistants' master degree projects.

What we here call "long distance fieldwork" highlights the role of the anthropological personae. As European anthropologists our fields became inaccessible with the political turmoil, at the same time as our Malian research assistants could continue to conduct fieldwork in the areas without exposing themselves to similar risks. This was initially an awkward situation. As ethnographers we are used to do fieldwork, and empirically document what is going on, regardless of whether "the field" is a hunters' movement, the local state or a political ritual. In a context when the anthropologist is herself/himself the prime methodological tool of the discipline, a critical question is how to work when the engagement that fieldwork entail is not possible any longer (see Hagberg \& Ouattara, 2012; Laurent, 2012). We find that the combination of using mass media and social media, of fieldwork pursued by our research assistants and, finally, of short fieldwork periods mainly in the capital opened up for another kind of conceptualisation of "the field" and of "fieldwork relations". Rather than the lonesome anthropologist interviewing and observing, we are a team working together and mutually exchanging information and ideas. The anthropological personae is different and, yet, still central even in this new research context. And we still strongly feel that this kind of anthropological research is important to pursue. In terms of the research assistants' position, they are pursuing their master degree fieldwork under the auspices of the research project, and we also pursue the comparative analysis drawing upon empirical evidence from Burkina Faso, Mali and Niger. In other words, although not really planned for we do think that this anthropological research is not just "the second best" to be applied when the field is inaccessible, but relies on a different kind of methodological strategy that is, in turn, likely to produce a slightly different kind of anthropological analysis.

Throughout the paper, we have tried to illustrate that choosing not to go to the field does not exclude an analysis of the situation and does not mean that one cannot incorporate these developments into an on-going research project. It is our contention that the production of anthropological knowledge should not be limited to only being based on first-hand ethnographic observation. Furthermore, there is also a danger of automat- 
ically equating fieldwork with representative authority - "having been there" - and of reducing the discipline of anthropology to the method of participant observation as this might lead to blindness to other kinds of empirical material ${ }^{11}$. In the long run it might also lead to the side-lining of anthropology in a global mediascape in which quick analysis and the creation of experts often on dubious grounds is prioritised over the grounded knowledge of anthropology.

\section{References}

AMID V. (ed.), 2000, Constructing the Field: Anthropological Fieldwork in the Contemporary World, London, Routledge.

BIERSCHENK T. and OLIVIER DE SARDAN J.P., 1997, "ECRIS : Rapid Collective Inquiry for the Identification of Conflicts and Strategic Groups ", Human Organization, 56(2): 238-244.

GRUENAIS M.-É., 2012, « L'anthropologie sociale est-elle inapplicable? L'exemple d'une "socio-anthropologie" dans les programmes de santé publique ", in Hagberg S. \& Ouattara F. (eds), «Engaging Anthropology for Development and Social Change ", APAD Bulletin, 34-36 : 61-79.

GUPTA A. \& FERGUSON J. (eds), 1997, Anthropological locations: boundaries and grounds of a field science, University of California Press, Berkley and Los Angeles.

HAGBERG S., 2002, "'Enough is Enough': An Ethnographic Account of the Struggle against Impunity in Burkina Faso ", The Journal of Modern African Studies, 40 (2), June 2002: 217-246.

HAGBERG, S. 2009. "Inventing and Mobilising the Local: Decentralisation and Citizen Participation in West Africa ", in Hagberg S. (ed.), " Inventing and Mobilising the Local ", APAD Bulletin, 31-32 : 3-34.

HAGBERG S., 2012, " Ifrågasätt svenska mediebilder av Afrika », Second Opinion, 9 May 2012, accessed 8 June 2013, www.second-opinion.se/so/view/2590.

${ }^{11}$ For an insightful discussion on this issue in the field of medical anthropology, see Gruénais (2012). 
HAGBERG S., KONE Y.F. \& ELFVING K., en collaboration avec Koné B., Traoré N. \& Diallo M., 2009, Analyse sociale au Mali : inclusion et exclusion à travers les opportunités du travail et de l'emploi, Uppsala, Swedish International Development Cooperation Agency.

HAGBERG S. \& KÖRLING G., 2012, " Socio-political Turmoil in Mali: The Public Debate Following the Coup d'Etat on 22 March 2012 ", Africa Spectrum, 47(2-3): 111-125.

HAGBERG S. \& OUATTARA F., 2012, «Introduction: Engaging Anthropology for Development and Social Change ", in Hagberg S. \& Ouattara F. (eds), "Engaging Anthropology for Development and Social Change », APAD Bulletin, 34-36: 9-28.

KOVATS-BERNAT C.J. 2002, « Negotiating Dangerous Fields: Pragmatic Strategies for Fieldwork amid Violence and Terror ", American Anthropologist, 104(1): 208-222.

LAURENT P.-J., 2012, «Engager l'anthropologie du développement à prendre en compte le malaise postcolonial ", in Hagberg S. \& Ouattara F. (eds), "Engaging Anthropology for Development and Social Change », APAD Bulletin, 34-36 : 29-60.

LESERVOISIER O. (ed.), 2005, Terrains ethnographiques et hiérarchies sociales: retour réflexif sur la situation d'enquête, Paris, Karthala.

NORDSTROM C. \& ROBBEN A., 1997, Anthropology Under Fire: Contemporary Studies of Violence and Culture, University of California Press.

OLIVIER DE SARDAN J.-P., 2005, « Classic ethnology and the socio-anthropology of public spaces: New themes and old methods in European African Studies ", Africa Spectrum, 40(3): 485- 497.

RICHARDS P. (ed.), 2005, No Peace, No War: An Anthropology of Contemporary Armed Conflicts, London \& New York, James Currey.

ROBBEN A.C.G.M. \& SLUKA J.A. (eds), 2007, Ethnographic Fieldwork: An Anthropological Reader, Malden \& Oxford, Blackwell.

SLUKA J.A. \& ROBBEN A.C.G.M., 2007, « Fieldwork in Cultural Anthropology: An Introduction ", in Robben A.C.G.M. \& Sluka J.A. (eds), Ethnographic Fieldwork: An Anthropological Reader, Malden \& Oxford, Blackwell.

SVERIGES RADIO, 23 March 2012, Studio Ett: Mali, accessed 8 June 2012, http://sverigesradio.se/sida/artikel.aspx?programid=1637\&artikel=50321 40 
SVERIGES RADIO, 22 August 2012, Kidnappad svensk i Mali: förhandlingar pågår, accessed 8 June 2013, http://sverigesradio.se/sida/artikel.aspx?programid=83\&artikel=5240450

SVERIGES RADIO, 29 January 2013, Situationen i Mali, accessed 8 June 2013, http://sverigesradio.se/sida/artikel.aspx?programid=1637\&artikel=54083 77

VAN DE WALLE N., 2012, "Foreign Aid in Dangerous Places: The Donors and Mali's Democracy ", WIDER Working Paper, 61, Helsinki, UNU-WIDER.

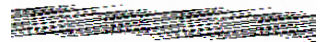

Sten Hagberg and Gabriella Körling, Department of Cultural Anthropology and Ethnology, Uppsala University E-mail : sten.hagberg@antro.uu.se

E-mail : gabriella.korling@antro.uu.se 